середовища.

Друга особливість полягає в тому, що найпродуктивніше учні оволодівають АМ у процесі мовленнєвої комунікації, коли вчитель та учні виступають рівноправними мовленнєвими партнерами. У цьому випадку стосунки між ними мають яскраво виражений суб'єктно-суб' єктивний характер і свідчать про володіння вчителем уміннями мовленнєвого партнерства. Не менш важливим є уміння вчителя організовувати спілкування в режимі «учень-учень» як моделі реального спілкування.

Третя особливість полягає в тому, що вчитель АМ є (для учнів) основним джерелом інформації про ті зміни, які відбуваються в мові та соціокультурній ситуації в країнах, мова яких вивчається. Це висуває високі вимоги до мовної та мовленнєвої компетенції вчителя АМ і вимагає їх постійного вдосконалення.

Отже, названі особливості не вичерпують специфіки процесу навчання АМ у навчальному закладі, а є лише виявом особливостей структури і змісту цього процесу. Безсумнівно, що ці та інші особливості мають знайти свої відображення в системі професійно-методичної підготовки студентів. Комплекс професійних умінь сприятиме підвищенню ефективності та підготовки майбутнього вчителя англійської мови початкової школи.

\title{
Література
}

1. Бондаренко О. Ф. Сучасні тенденції професійної підготовки вчителя IM для початкової школи / О. Ф. Бондаренко, О. Б. Бігич // Іноземні мови. - 2002. - № 4. - С. 48. 2. Сафонова В. В. Социокультурный подход к обучению иностранным языкам / В. В. Сафонова. - Москва: Высшая школа, 1991. - 305 с. 3. Тамбовкина Т. Ю. Развитие профессиональной автономии у будуших учителей иностранного языка с использованием метода проектов / Т. Ю. Тамбовкина // Иностранный язык в школе. - 2000. - № 5. - С. 63.

УДК 37.013 .42

Ольга Василенко

\section{РОЛЬ СОЦАЛЬНОЇ КОМПЕТЕНТНОСТІ В РОЗВИТКУ СОЦІАЛЬНОЇ ВІДПОВІДАЛЬНОСТІ УЧНІВ У МІКРОСЕРЕДОВИЩІ}

Василенко О. М. Роль соціальної компетентності в розвитку соціальної відповідальності учнів у мікросередовищі.

У статті на основі аналізу сучасних досліджень розглядається соціальна відповідальність як механізм соціальної компетентності, що сприяє співробітництву в групі на основі обізнаності про соціально-правові норми співпраці, готовності виконувати обов'язок та нести відповідальність за свої дії. Автор уточнює вміння, що забезпечує формування соціальної компетентності учнів, розкриває значення принципу субсидіарності в розвитку соціальної відповідальності учнів на основі формування певної рефлексивної позиції учнів із використанням прийомів формування відповідальності за свої вчинки. Доведено, що якість оволодіння соціальною компетентністю учнями сприяє відтворенню та розвитку соціальної відповідальності на індивідуальному і мікросередовищному рівнях.

Ключові слова: соціальний, компетентність, співробітництво, відповідальність, обов'язок, принцип субсидіарності, мікросередовище.

Василенко О. Н. Роль социальной компетентности в развитии социальной ответственности учащихся в микросреде. 
В статье на основе анализа современных исследований рассматривается социальная ответственность как механизм социальной компетентности, способствующий сотрудничеству в группе на основе осознания социально-правовых норм сосуществования, готовности исполнять обязанности и нести ответственность за свои действия. Автором уточнены умения, обеспечивающие формирование социальной компетентности учащихся, раскрыто значение принципа субсидиарности в развитии социальной ответственности учащихся, рефлексивной позиции учащихся с использованием приёмов формирования ответственности за свои действия. Доказано, что овладение социальной компетентностью способствует развитию и реализации социальной ответственности на индивидуальном уровне и уровне микросреды.

Ключевые слова: социальный, компетентность, сотрудничество, ответственность, обязанность, принцип субсидиарности, микросреда.

Vasylenko O. M. The role of social competence in the development of students' social responsibility in the microenvironment.

The article based on the analysis of current research deals with the social responsibility as a mechanism of social competence, which promotes cooperation in groups on the basis of knowledge about social and legal norms of cooperation, willingness to have a duty and be responsible for one's actions. The author defines the skills that allow the formation of students' social competence, reveals the meaning of the subsidiarity principle in the development of student social responsibility on the basis of the formation of a specific reflective position of students using techniques of formation of responsibility for their actions. It is proved that the quality of mastering the social competence by students promotes easier development and implementation of social responsibility at an individual level and microenvironmental one.

Key words: social, competence, cooperation, responsibility, duty, subsidiarity principle, microenvironment.

В умовах демократизації суспільство посттоталітарної України, що набуває ознак інформаційного суспільства, об'єктивно орієнтоване на вироблення особистістю соціальної компетентності. Саме соціальна компетентність як продукт нового знання у сфері суспільних відносин $є$ двигуном розвитку інформаційного суспільства. Соціальна відповідальність $є$ одним із складників як соціального розвитку суспільства (побудови громадянського правового суспільства), так і соціального розвитку індивіда - набуття відповідальності як соціального досвіду і ціннісних орієнтацій через сімейні, етнічні, громадянські, регіональні цінності та їх самореалізацію у мікросоціумі (сім'я, група, громада), що посилює соціальну компетентність самої особистості.

Актуальність дослідження зумовлена розумінням суспільством значущості соціальної відповідальності, проте сама відповідальність, процес іiі формування зазнають значних змін у нових соціокультурних умовах. Соціальна компетентність, безумовно, впливає на розвиток соціальної відповідальності, динаміка якої має починатися в мікросоціумі та відбуватися за нових принципів, відповідних до перетворень сучасності.

Аналіз останніх досліджень і публікацій, у яких започатковано розв'язання досліджуваної проблеми, показав, що термін «відповідальність» 3'явився наприкінці XVIII століття як результат функціонуванням політичних інститутів за принципом суспільної організації. Поняття «соціальна відповідальність», як підзвітність суб'єкта перед інстанціями, спільнотою, мікросоціумом (сім'я, рід, близьке оточення) упроваджено в 
науковий обіг філософами, соціологами та психологами понад століття тому. Сучасні науковці проблему соціальної відповідальності досліджували в різних аспектах: О. Безрукава, І. Вітковська, А. Срмоленко, А. Кравченко (філософський); В. Андрущенко, В. Бех, О. Линовицька (соціокультурний); І. Акімова, Х. Гальчак, С. Мельник (економічний); I. Аземша, Н. Берлач, С. Братусь, І. Маяк (юридичний); Л. Буєва, М. Лукашевич, П. Мінкіна, Т. Парсонс (соціологічний); Е. Бекірова, М. Васильєва, А. Кравченко, М. Левківський, С. Мукомел, Н. Стаднік, В. Тернопільська, Т. Фасолько (педагогічний). Незважаючи на багатоаспектність феномену соціальної відповідальності, міждисциплінарний аналіз поняття показує, що соціальна відповідальність пов'язується із соціальністю особистості, $є$ складником взаємовідносин між людьми та змінюється відповідно до динаміки соціальних цінностей історичної епохи.

Мета статmі- на основі аналізу сучасних досліджень розкрити роль соціальної компетентності у розвитку соціальної відповідальності учнів у мікросередовищі.

У науковій літературі соціальну відповідальність розглядають як: необхідний регулятив спільної життєдіяльності індивідів, співмірний ідеальному образу майбутнього 3 соціальним контекстом, у якому вона буде актуалізуватися (А. Кравченко) [2]; якість, що характеризує соціальну типовість особистості у поведінці, діяльності відповідно до соціальних норм певного суспільства (М. Левківський) [4]; взаємозв'язок виконання людиною дій i обов'язків, що входять до структури іiі соціальної компетентності, іiі громадянських обов'язків (О. Пономарьов, М. Чоботарьов) [6]; здатність особистості формулювати свої обов'язки, виконувати їх, здійснювати самооцінку та контроль за ними, центральним утворенням яких $є$ моральна духовність особистості, що реалізується в самостійності, ініціативності, готовності відповідати за наслідки своїх дій (Т. Федорченко) [9]. Отже, соціальна відповідальність не зводиться до виконання обов'язків, вона розглядається як складна соціально-моральна особистісна якість, зумовлена розвитком індивіда, його соціальною компетентністю, активністю в діяльності та визначається внутрішніми і зовнішніми чинниками.

У сучасних дослідженнях розглядають проблему відповідальності, під якою розуміють особистісну основу відповідальної поведінки учнів. Останню в дослідженнях конкретизують так: смислове утворення особистості, своєрідним загальним принципом співвіднесення в межах цілісної мотиваційно-смислової сфери мотивів, цілей та засобів життєдіяльності (М. Савчин); інтегрована моральна властивість, яка виявляється у здатності учня соціально доцільно поводитись у школі, сім'ї, предметному середовищі, конструктивно взаємодіяти з ровесниками і дорослими, усвідомлено ставитись до їхніх вимог, реалізовувати відповідно до морально-етичних принципів і вікових можливостей свої права та обов'язки, критично оцінювати власну поведінку та вчинки як корисні чи шкідливі для себе та інших (Т. Куниця) [3]. Автори виокремлюють основні структурні компоненти відповідальної поведінки учнів, узагальнений зміст яких представлено як: когнітивний (знання про соціальні норми, цінності і правила відповідальної поведінки; соціальні уявлення та розуміння соціальної дійсності; розуміння суті і предмета відповідальності; усвідомлення обов'язків на рівні соціуму, групи); емоційно-ціннісний (позитивна спрямованість у взаємодії, засвоєння й осмислення ціннісних орієнтацій; суб'єктивне ставлення до соціуму, оточуючих і до самих себе через емоційно позитивне сприйняття); мотиваційний (цілі та мотиви, що спонукають, спрямовують, регулюють відповідальну поведінку, сформованість мотиваційної основи поведінки, де домінуючими є мотиви суспільні, морального самоствердження та самореалізації, через які розкриваються їхні соціальні домагання); 
практичний (набуття умінь і навичок відповідальної поведінки та свідоме їх дотримання; виконання обов'язків, дотримання норм, морально-етичних вимог, зобов'язань; відповідальне ставлення до себе, до інших, за доручені справи; ініціатива до прийняття обгрунтованих рішень у складних ситуаціях, відповідальність за них). Це, у свою чергу, вимагає конкретизації цілей, завдань щодо соціальної компетентності учнів, яка містить знання у сфері суспільних відносин та соціальної відповідальності.

Зазначимо, що становлення і закріплення соціальної відповідальності учнів відбувається в процесі інституціалізації освіти, яка набуває характеру соціального процесу (А. Кравченко) [2]. Виходячи з цього, соціальну компетентність учнів будемо розглядати як здатність до співробітництва в групі, уміння адаптуватися, визначати особисті цілі та виконувати різні ролі й функції в колективі: планувати, розробляти й реалізовувати соціальні проекти індивідуальних і колективних дій на основі обізнаності про соціально-правові норми співпраці, готовність нести обов'язок та відповідати за свої вчинки. Соціальна компетентність має на меті: формування знань, умінь та дій правильно організовувати соціальний простір на основі усвідомлення необхідності діяти згідно із суспільними вимогами та нормами як соціальними цінностями. Якість оволодіння соціальною компетентністю сприяє відтворенню та розвитку соціальної відповідальності - від індивідуального рівня (особистість) до середовищного (сім'я, група, громада). На актуалізацію та реалізацію соціальної відповідальності учня, групи, громади і спрямований принцип субсидіарності соціально-педагогічної діяльності.

Уперше у вітчизняний науковий простір субсидіарність як принцип соціальної роботи увела І. Звєрєва, узагальнюючи роботи Й. Альтузіус, К. Амарал, Н. Анисимової, Г. Гегеля та виступи сучасних німецьких науковців. В енциклопедичному словнику з соціальної роботи зазначено, що «субсидіарність - у світовій практиці - законодавче регулювання взаємодії державних і недержавних структур у соціальному секторі, що передбачає надання переваги при фінансуванні громадським (суспільним), приватним ініціативам у галузі соціальних програм і заходів у порівнянні 3 державними [8]. Субсидіарність, за Т. Панченко, є в демократичному суспільстві регулятором стосунків людей, соціальних спільнот і суспільства щодо захисту свобод і відповідальності індивіда, групи, громади та надання підтримки «...щоразу, коли індивідуальної свободи і відповідальності недостатньо для досягнення цілей, необхідних для підтримки людської гідності» [5, с. 248]. А. Рижановою обгрунтовано актуалізацію за інформаційної доби принципу субсидіарності соціально-педагогічної діяльності. Авторка цей принцип характеризує як захист відвладних структур індивідуальної свободи та відповідальності людей, соціальних спільнот, суспільства загалом та водночас підтримку державою або місцевою владою індивідуальної свободи і відповідальності, коли їх недостатньо для досягнення цілей, необхідних для вкорінення людської гідності [7].

Соціальна відповідальність учнів може бути перед власною совістю, іншою людиною, суспільством, окремим соціальним інститутом. Тому для посилення міри соціальної відповідальності учнів принцип субсидіарності вимагає глибокого і всебічного вивчення іiі особистості, а саме: характеру стосунків у сім’і, із однокласниками, друзями, рівня сформованості моральних якостей. Знання особливостей розвитку дитини дозволяє організувати різні види діяльності, спілкування дитини, що забезпечує розкриття iํ потенціалу, створюючи умови для ії самореалізації, саморозкриття.

Соціальна відповідальність учнів різного віку може наставати в результаті здійснення контролю над діяльністю і поведінкою суб'єкта 3 огляду на свідоме виконання ним прийнятих норм і вимог, дає їм оцінку та грунтується на почутті обов'язку. Водночас для 
розвитку соціальної відповідальності необхідно створювати умови в мікросередовищі для стимулювання дитини до самоактуалізації, самоконтролю. Це передбачає формування певної рефлексивної позиції, а саме: усвідомлення потреби, бажання змінювати себе, удосконалювати свої особистісні якості; самоаналіз; самооцінка; визначення мети, алгоритму діяльності, спрямованої на самозміну, самовдосконалення. Для формування готовності відчувати обов'язок і нести відповідальність за свої вчинки можна використовувати прийоми, спрямовані на самозміну: самообов'язки, самонакази, самопримушення, самоутворення, самопереконання, самоінструктування, самопереключення, самонагадування, самонавіювання, самозаохочення, самопокарання, самоконтроль, самооцінка, самокореляція діяльності.

У педагогічній науці розроблено цілий арсенал механізмів формування соціальної компетентності учнів. Було встановлено, що саме соціальна відповідальність є одним із механізмів формування соціальної компетентності. 3 урахуванням характеристики соціальної відповідальності учнів як усвідомлення обов'язку, почуття та волі, які проявляються у виборі рішення (особистісного, колективного), у груповій діяльності відповідно до соціальних норм та обов'язків у навчанні охарактеризовано вміння, що виступають механізмом змін у соціальній компетентності учнів: вміння робити вибір (цілевизначення відбору засобів досягнення мети, ефективне перероблення інформації); уміння приймати рішення (довільне та рефлексивне перероблення знань у свідомості, формування цінностей, моделювання реалізації мети комунікації відповідно до обставин); уміння брати на себе відповідальність (виконання рішень, оцінювання одержаних результатів); вміння безконфліктно співіснувати (розв'язання проблеми в різних життєвих ситуаціях; аналіз, балансування власних особливостей з об'єктивними вимогами ситуації).

Отже, аналіз аспектів феномену соціальної компетентності учнів у сфері суспільних відносин та соціальної відповідальності виявляє його багатогранність і багатоманітність, свідчить про його достатньо важливу роль в індивідуальному і суспільному житті людини, а особливо учнів в умовах компетентної освіти. Розроблено вміння, що забезпечує механізм розвитку соціальної компетентності учнів (робити вибір, приймати рішення, брати відповідальність, безконфліктно співіснувати) та сприяє організації соціально-виховного процесу логічно і цілеспрямовано. Розвиток соціальної відповідальності побудований за принципом субсидіарності, який стимулює самостійність, активність у задоволенні власних соціальних потреб дитиною та різноманітними соціальними групами (сім'я, однолітки, загальноосвітній навчальний заклад) через вдосконалення мікросередовища. Розвиток соціальної відповідальності неможливий без формування певної рефлексивної позиції учнів (усвідомлення потреби до самозмін, самовдосконалення; самоаналіз; самооцінка) 3 використанням прийомів (самообов'язки, самонакази, самопереконання, самоінструктування, самонагадування, самоконтроль, самооцінка, самокореляція), формування готовності відчувати обов'язок та нести відповідальність за свої вчинки. Це дозволить учням адекватно сприймати ціннісний сенс суспільних взаємовідносин i максимально його використовувати.

Проведене дослідження, безумовно, не претендує на повноту i завершеність. Подальшого дослідження потребують такі аспекти проблеми, як створення системи розвитку соціальної відповідальності учнів в умовах компетентнісної освіти.

\section{Література}

1. Звєрєва І. Д. Про організацію допомоги молоді Німеччини: структура та завдання / І. Д. Звєрєва // Довіра і надія. - 1994. - №3. - С. 31-33. 2. Кравченко А. А. Свобода i 
відповідальність як умова саморозвитку особистості в освіті / А. А. Кравченко // Нова парадигма : [журнал наук. праць] / гол. ред. В.П.Бех; Нац. пед. ун-т імені М. П. Драгоманова; творче об’єднання «Нова парадигма». - Вип. 114. - Київ : Вид-во НПУ імені М. П. Драгоманова, 2013. - С. 42-50. 3. Куниця Т. Ю. Виховання відповідальної поведінки в учнів 7-8-х класів загальноосвітньої школи : автореф. дис. ... канд. пед. наук : 13.00.07 - теорія і методика виховання / Куниця Тетяна Юріївна. - Київ, 2008. - 23 с. 4. Левківський М. В. Критерії та рівні розвитку відповідального ставлення до праці / М. В. Левківський // Рідна школа. - 1993. - № 11-12. - С. 54-56. 5. Панченко Т. В. Принцип субсидіарності в сучасному демократичному розвитку: [монографія] / Т. В. Панченко.Харків : Майдан, 2011. - 361 с. 6. Пономарьов О. С. Відповідальність в системі професійної компетентності фахівця : [навч.-метод, посіб.] / О.С. Пономарьов, М. К. Чеботарьов. Харків : Підручник НТУ «ХПІ», 2012. - 220 с. 7. Рижанова А. О. Розвиток соціальної суб'єктності та принцип субсидіарності соціально-педагогічної діяльності / А. О. Рижанова // Педагогіка та психологія: [зб. наук. праць]/ за заг. ред. академіка I. Ф. Прокопенка, проф. С. Т. Золотухіної. - Харків : Вид-во ТОВ «Щедра садиба плюс», 2015. - Вип.48.260 с. 8. Субсидіарність // Соціальна робота. Короткий енциклопедичний словник. - Київ : ДЦССМ, 2002. - Кн. 4. - С. 460. 9. Федорченко Т. Є. Соціально-педагогічні засади профілактики девіантної поведінки школярів в умовах соціокультурного середовища : дис... доктора пед. наук : спец. 13.00.05; Держ. заклад «Луган. нац. ун-т ім.. Тараса Шевченка» / Тетяна Євгенівна Федорченко. - Луганськ, 2013. - 561 с.

\section{ВПЛИВ КОМУНІКАТИВНОГО ТА ТРАДИЦЙНИХ МЕТОДІВ НАВЧАННЯ ІНОЗЕМНОЇ МОВИ В ПОЧАТКОВІЙ ШКОЛІ НА СТАНОВЛЕННЯ ТВОРЧОЇ ОСОБИСТОСТІ МОЛОДШОГО ШКОЛЯРА}

Васильєва О. В. Вплив комунікативного та традиційних методів навчання іноземної мови в початковій школі на становлення творчої особистості молодшого школяра.

Стаття присвячена аналізу ролі традиційних методів навчання іноземної мови та висвітлює позитивні й негативні аспекти використання комунікативного методу в початковій школі. Автор аналізує провідні методики, що застосовуються для формування комунікативної компетентності молодших школярів.

Ключові слова: комунікативна компетентність, комунікативний метод, традиційні методи, початкова школа, молодші школярі.

Васильева О. В. Влияние коммуникативного и традиционного методов обучения иностранному языку в начальной школе на становление творческой личности младшего школьника.

Статья посвящена анализу традиционных методов и коммуникативного подхода в процессе преподавания иностранного языка в начальной школе, обозначены позитивные и негативные аспекты использования коммуникативного метода в начальной школе. Автор анализирует ведущие методики, которые используются для формирования коммуникативной компетентности младших школьников.

Ключевые слова: коммуникативная компетентность, коммуникативный метод, традиционные методы, начальная школа, младшие школьники. 